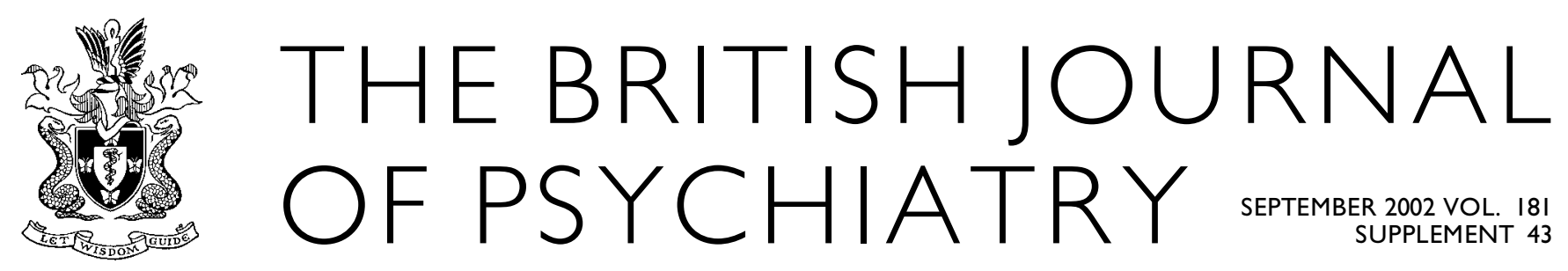

PUBLICATION OF THIS SUPPLEMENT WAS MADE POSSIBLE BY AN UNRESTRICTED EDUCATIONAL GRANT FROM ASTRAZENECA

\title{
European First-Episode Schizophrenia Network
}

EDITED BY SHÔN LEWIS 